\title{
Canonisation and Documentation of Interdisciplinary Electroacoustic Music, Exemplified by Three Cases from the Netherlands: Dick Raaijmakers, Michel Waisvisz and Huba de Graaff
}

\author{
HANNAH BOSMA \\ Alexanderkade 30, 1018 CL Amsterdam, The Netherlands \\ Email: mail@hannahbosma.nl
}

\begin{abstract}
Relations between histories, sources and preservation problematics are explored by evaluating how Dutch electroacoustic musical life is discussed in international histories of electronic music. Some Dutch cases consisting of different generations of interdisciplinary, live, performancebased electroacoustic work are discussed: the work of Dick Raaijmakers, Michel Waisvisz and Huba de Graaff. These cases point to some important aspects of preservation and the formation of histories. An emphasis in electronic music histories on technology and on technological innovation comes at the expense of information on the musical and artistic aspects. For greater interest in musical aspects, it is crucial to have more access to the music itself. The works and practices of Dick Raaijmakers, Michel Waisvisz and Huba de Graaff seem to resist documentation, ontologically and practically but, on the other hand, there is a desire for its documentation and dissemination. For their work, preservation means: making something new while being faithful to the past. It is therefore that I propose to regard preservation as performance. This music only remains alive when we are not solely interested in linear innovation, but in a profound relation with the past, in reworking the past.
\end{abstract}

\section{INTRODUCTION}

To consider the possibility of alternative histories, it is important to reconsider the existing histories and their sources. Where do the histories come from? The availability and accessibility and the choice of sources are an important aspect of the formation of music history. Analytical and historical accounts are often confined to music of which accessible documentation or audio(visual) recordings are available; this is a problem for music that does not fit into established formats or for which scores or standard audio(visual) recordings are not available (see, for example, Bosma 2006, 2013). The lack of available resources is not only a disadvantage with regard to contemporary accounts and analyses of such musical art; the long-term preservation of such music is also seriously problematic (see, for example, Canazza and Vidolin 2001; Battier 2004; Roeder 2004, 2008; Bosma 2005, 2007, 2016a; Emmerson 2006; Polfreman, Sheppard and Dearden 2006; Wetzel 2006; Douglas 2007; Guercio, Barthélemy and Bonardi 2007; Longton 2007; Cuervo 2008). It specifically affects music that has one or more of the following characteristics: interdisciplinary, exclusively performance-based, participatory, in the form of an installation, live electronic, improvised, with custom-made instruments or equipment. The availability and accessibility of historical sources is related to the preservation problematic; for electroacoustic music in particular, preservation is a complex problem. What is left of the past?

In this article, I will explore the relations between histories, sources and preservation problematics by evaluating how Dutch electroacoustic musical life is discussed in international histories of electronic music. Who are mentioned, and why? What aspects of their work are mentioned? Is the availability of musical sources, such as scores and recordings, important for the inclusion in or exclusion from historical accounts? I will start with the question about the kind of source materials used in some of the main historical overviews of electronic music. I will also discuss the focus of these histories and the selection criteria this implies, by tracing how Dutch music is represented in these histories. Then I will discuss some Dutch cases consisting of different generations of interdisciplinary, live, performancebased electroacoustic work: the work of Dick Raaijmakers, Michel Waisvisz and Huba de Graaff. How is their work represented in the main histories of electroacoustic music? What sources are available? How is their work preserved? These cases point to some important aspects of preservation and the formation of histories. 


\section{MUSIC HISTORIES}

\subsection{The focus of (electronic) music histories}

Music history is different from most other forms of history. It has two faces, two functions. Music history not only gives an account of how things were in the past and how they developed, but also deals with the here and now: music histories are guides to how we listen to and perform music in the present. The music of the past is performed and listened to in the here and now; it is part of contemporary musical culture. We not only want to read about music of the past, but we also want to listen to it or perform it in the present. Therefore, primary musical sources that form the 'music itself', such as scores and recordings, have a double role: as sources on which historical accounts are based and as music that can be experienced in the present.

Donald Jay Grout stated in the preface to his third edition of $A$ History of Western Music:

The history of music is primarily the history of musical style and cannot be grasped except by first-hand knowledge of the music itself. It is therefore essential to become acquainted with the sound of the music discussed [...] and to be able to examine it more or less in its entirety. (Grout 1980: xi)

For Grout, the music itself was so important that he had doubts about the merits of a music history:

'Is not the music itself enough?' How can writing about a composition's history enhance what listeners hear? (Grout, quoted in Swift 2011: 140)

Grout's book is replete with descriptions of musical pieces and score examples. Moreover, the book is coupled with Palisca's score source anthology. The later editions of A History of Western Music by Burkholder go with an anthology of recordings as well (Burkholder, Grout and Palisca 2014). Later music history books do focus more on cultural and political contexts than Grout's early editions, but still devote much attention to the music itself, by way of descriptions, analyses and score examples: Robert Morgan's Twentieth-century Music (Morgan 1991) is, like Grout's work, accompanied by a musical score anthology; Taruskin (2005) gives quite extensive analyses of key musical works, with printed score examples, as does Griffiths (1981).

Several books on electronic music contain historical overviews and discuss the development of electronic music more or less chronologically, although these books are not called 'histories' in their titles. ${ }^{1}$ These

${ }^{1}$ In this article, for the historical accounts of electronic music, I focus on Chadabe (1997), Collins, Schedel and Wilson (2012), Manning (2013) and Holmes (2016), which are the main overviews of electronic music at this moment; the books by Holmes and Manning are especially significant as both have been in print since 1985 , have been updated with each new version and now are in their fifth and fourth electronic music histories have a different focus from the more general music history books: they deal not only with the music, but also, to a great extent, with the electronic music technology. ${ }^{2}$ Electronic music history is to a large extent structured according to technological developments, whereas general music history books (such as Burkholder/Grout) are mainly structured according to time periods, geographical areas and musical styles, forms, traditions and developments, rather than, for example, dealing extensively with the technical aspects of musical instruments. Davies (2001) criticised the historical accounts of Western classical music for barely paying attention to musical instruments:

Musical instruments are always treated by non-specialists as the 'poor relation'. Depending on the context, the normal focus is either on what is ultimately the only really important aspect, the sounding of music in performance, or else on the lives of its major composers and, especially in recent years, of its star performers. After these come other considerations, such as music's written-down notation, the accuracy of surviving manuscripts and the different versions of a composition, the authentic manner of performing earlier music, and so on. Last of all are the sources of all the sounds, the instruments themselves, which are almost always taken for granted, apart from the occasional mention of a Stradivarius violin, a Ruckers harpsichord or a Steinway piano.

The general impression of Western musical instruments based on those that participate in the modern symphony orchestra (plus the piano, pipe organ, acoustic guitar and occasionally the saxophone) is that these are completely standardized and interchangeable. But this is by no means the case, and never has been[.] (Davies 2001: 295)

For (experimental/avant-garde) live electronic art music, there is far less standardisation of electronic

(Fnote continued)

edition respectively. I do not discuss older accounts such as Prieberg (1960), because my focus here is on the history of electronic music as it is currently presented.

${ }^{2}$ For example, Holmes (2016) discusses (predecessors of) electronic musical instruments in the first chapter, principles of electronic music technology in a section on 'Tape Composition Methods and Techniques' and in a chapter on 'Principles of Analog Synthesis and Voltage Control', early synthesisers in Chapter 6, etc.; Part II 'Ana$\log$ Synthesis and Instruments' and Part III 'Digital Synthesis and Computer Music' are structured according to technical aspects (Part IV is called 'The Music') and all chapters are infused with technical information and pictures of equipment, diagrams, etc. Manning (2013) provides even more detailed technical information and is to a large extent structured according to technological developments as well. Chadabe (1997) is partly structured according to technological developments as well, but is less concerned with technological details and more with technological-historical (incl. business/industry) and musical-cultural developments, not providing diagrams and explanations of technological principles, but accounts of persons who were actors in the development of electronic music. Collins et al. (2012) offers a broad overview of electronic music, extending more into the realm of popular music and into interdisciplinary domains and being more structured according to musical-cultural-social developments and less focused on pure music technology than the other historical overviews, and offering a few detailed musical analyses. 
musical instruments than in classical Western art music; thus, it seems logical that there is more attention for the instruments (and their related technology) in the electronic music histories. However, Davies's critique is to the point. Electronic music histories could learn from general Western art music histories to pay more attention to the music, but, inversely, electronic music histories may serve as an example for a different way of writing general music history.

\subsection{The sources of (electronic) music histories}

Music history books often do not mention all their sources precisely. (Since these books are often targeted at undergraduate students and interested readers, one may infer that too many references would make such books less accessible to such readers.) As a result, histories such as these seem an account of established facts instead of based on someone's perception and interpretation of specific sources.

What kind of sources are the histories of electronic/ electroacoustic music based on? The sources of the books on electronic music history ${ }^{3}$ mainly consist of books and articles, as well as liner notes, catalogues, manuals, and articles and interviews on websites. The books contain photographs, as well as diagrams, schematics and a few score excerpts. Chadabe (1997) in particular, but Holmes (2016) as well, quotes personal communication with composers and other key figures, thus providing new source material. Music recordings figure in lists of recommended listening material, ${ }^{4}$ but are seldom directly and specifically referenced as sources. ${ }^{5}$ Remarkably, the histories of electronic music deal less with the music itself than the histories of Western art music: there are fewer musical descriptions, analyses and examples; the electronic music histories also deal with the technology and the culture around the technology (studios, institutes, groups).

Most music that is discussed more in depth in the electronic music histories is recorded music or welldocumented music with scores and composers' explanations such as compositions by Karlheinz Stockhausen and John Cage. All pieces of the Listening Guide and Listen Playlists of Holmes are compositions of which recordings are available. In Holmes's Listening Guide, mostly tape music compositions are discussed. Tape music is easier to preserve than live electronic music (Bosma 2005; Emmerson 2006).

The archiving and preservation of electroacoustic music is now well established for fixed format ('tape') works. [...]

\footnotetext{
${ }^{3}$ See note 1 .

${ }^{4}$ Additionally, Holmes provides some audio tracks on the website that accompanies the book, as well as a list of links to videos and links to websites.

${ }^{5}$ Exceptions are for example the detailed discussions of and references to tracks from Lil Louis, Muslimgauze, Merzbow and Blectum from Blechdom by Collins et al. (2012: 115-18, 146-9).
}

The same cannot be said by a long way for 'live electronics'. (Emmerson 2006: 209)

Much preservation of tape music consists of stereo format recordings (Teruggi 2004); and tape music is distributed in stereo format on CD releases. ${ }^{6}$ Thus, preservation and availability of tape music may go hand in hand; and the availability of tape music recordings furthers its discussion in electronic music histories.

\section{DUTCH ELECTRONIC MUSIC IN INTERNATIONAL HISTORIES}

How is Dutch music represented in the histories of electronic music?

In the Netherlands, there is a variety of electroacoustic music: music for tape or other fixed media, live electronics, combined with classical acoustic instruments, as improvised music, sound art, installations, sound walks, electroacoustic music theatre, opera, applications for mobile devices, etc. ${ }^{7}$ There are several conservatories where electronic music composition or technology can be studied. Besides, there is a rich avant-garde and experimental musical culture outside academia for composed and improvised music, often combined with electronics. Moreover, the Netherlands has been important with regard to the development of house, techno and dance music, which is currently a significant cultural export product (van Bergen 2013). ${ }^{8}$

However, in the histories of electronic music we can find very little on this. ${ }^{9}$ What we do find is mainly related to pioneering studios:

- the Philips studio (1956-60), where Varèse's Poème Électronique was made, with associated composers Henk Badings, Dick Raaijmakers (as Kid Baltan) and Tom Dissevelt (Collins et al. 2012: 83-4;

\footnotetext{
${ }^{6}$ With 'stereo format', I refer here to recordings that technically consist of two channels/tracks ('left' and 'right') and not to the presence of a stereophonic illusion.

${ }^{7}$ For an impression of various approaches in Dutch electronic music, see Oskamp (2011). For a detailed study of the development of Dutch electronic music between 1925 and 1965, including the early work of Dick Raaijmakers, see Tazelaar (2013).

${ }^{8}$ See also (in Dutch) www.ing.nl/nieuws/nieuws_en_persberichten/ 2013/10/in_het_nieuws_dance_is_serieuze_business.html\#! (16 October 2013, accessed 6 January 2017), www.eenvandaag.nl/binnenland/ 54590/_dancemuziek_wordt_h_t_exportproduct_van_nederland (15 October 2014, accessed 6 January 2017), www.bumastemra.nl/exportwaarde-nederlandse-populaire-muziek-wederom-gestegen/ (16 January 2016, accessed 6 January 2017).

${ }^{9}$ With regard to the early electronic music: a much more inclusive overview of early electronic music compositions in the Netherlands, in which particularly the many compositions of Jan Boerman, Ton Bruynèl and Dick Raaijmakers stand out, was already offered in Davies's catalogue of electronic compositions (Davies 1968); see also Mooney (2015). So the selection of early Dutch electronic music can not be due to ignorance of the existence of other electronic music in the Netherlands
} 
Manning 2013: 72, 148; Holmes 2016: 3, 95-7, 376-9, 474-6, 511);

- the ensuing Institute of Sonology (mainly the period at Utrecht University, until 1986) and its associated composers and researchers, such as Gottfried Michael Koenig, Werner Kaegi and Stan Tempelaars, and the computer programmes and synthesis techniques they developed (Chadabe 1997: 169-71, 241-2, 256, 280-3; Collins et al. 2012: 122; Manning 2013: 72, 129, 148-9, 203-6; Holmes 2016: 98, 298-9, 535);

- the Studio for Electro-Instrumental Music STEIM (since 1969) and/or its director (since 1981) inventorcomposer-performer Michel Waisvisz (1949-2008) (Chadabe 1997: 228, 241-2; Collins et al. 2012: 184; Manning 2013: 454-5, 456; Holmes 2016: 284-5, 535).

This choice seems to be related to a focus on technological innovation and institutional structures instead of on musical or artistic developments. ${ }^{10}$ In the following part of this article, I will take a closer look at some cases of Dutch electroacoustic music and speculate on why these were or were not included in the international histories of electronic music.

\subsection{Dick Raaijmakers (1930-2013) ${ }^{11}$}

\subsubsection{Dick Raaijmakers: work and documentation}

Dick Raaijmakers, composer, artist, theorist, writer and teacher, was unique, remarkable and very influential in the Netherlands. His work is conceptually, musically and artistically profound and precise. His tape music, his musical performance art, his sound installations and his music theatre deal with the medium, with electroacoustic technology and with musical culture in a highly original and subversive way. For example, his Intona (1992) consists of various processes to destroy a microphone. ${ }^{12}$ In $\mathrm{Der}$ Fall Leiermann (1991), based on Schubert's song

\footnotetext{
${ }^{10}$ There are a few other Dutch composers that are mentioned. Holmes (2016: 235) mentions Marko Ciciliani (born in former Yugoslavia, grown up in Germany, based in the Netherlands 1996-2010, now based in Austria) for his work with 'no-input mixer' (2002, 2007), which is only a small part of his oeuvre. Bert Bongers (originally from the Netherlands, now working in Australia) is mentioned in Manning (2013) for his collaboration in the Meta-Orchestra, and discussed by Manning in the context of laptop and network music (419). Chadabe discusses Felix Visser and his Synton synthesiser system (1997: 18991, 199-200). This, again, shows a focus on technical instead of musical criteria. On the other hand, there is a brief mention of the video opera The News of JacobTV (188) and Dutch dance music (109) in Collins et al. (2012) and a discussion of Felix Hess in Chadabe (1997: 306-8)

${ }^{11}$ I would like to thank Anne Wellmer for her comments on this section.

${ }^{12}$ For a video recording of a performance at V2 ('s-Hertogenbosch, the Netherlands) in 1992 and more information, see http://v2.nl/ archive/works/intona, www.youtube.com/watch?v=udoD2m_KTdw and www.youtube.com/watch?v=qI6S6hyV9MY (full version) (accessed 18 September 2016).
}

'Der Leiermann', Raaijmakers turned an analogue tape on a reel-to-reel tape recorder by hand. ${ }^{13}$ The three Ideofonen (1970) are large and technically complicated installations consisting of loudspeakers that generate their own sound. ${ }^{14}$ Raaijmakers's work is often interdisciplinary and related to the visual arts. Collaboration was an important aspect of his work, whether in student projects or in large music theatre productions.

Dick Raaijmakers's attitude towards the preservation of his work was twofold. On the one hand, his performance and theatrical works were focused on the moment itself, both ideologically and practically, and they were the result of unique collaborations. On the other hand, Raaijmakers kept an elaborate personal archive. And when there was a good opportunity for documentation, he worked on it intensely, writing meticulously precise and elaborate texts, providing detailed drawings, etc. What he did not want was packaging his music in the standard format of a score that could be performed by anyone. Performances of his work were special events. His complete tape music, with a substantial booklet with elaborate documentation on the compositions, in Dutch with a complete English translation, was released as a CD box set in 1998 and rereleased in 2006 (The Complete Tape Music of Dick Raaijmakers 1998). His performance and music-theatrical works and his installations are far more difficult to document and disseminate, as they were focused on the unique moment. However, in 2007, an enormous book weighing three kilograms was published that extensively documented his musictheatrical and performance work and installations with text and photographs (Mulder and Brouwer 2007); the English translation appeared in 2008. And, while Raaijmakers was first resistant to reperformance (every performance is a new performance), at the end of his life several re-performance and re-installation projects were produced by people who had worked with him before. Moreover, after the publication of the Monograph Raaijmakers donated his archive to the Netherlands Music Institute in The Hague. In the last few years, the archive has been processed and taken care of at the Institute of Sonology of the Royal Conservatoire in The Hague, the Netherlands (Kees Tazelaar and Anne Wellmer).

\footnotetext{
${ }^{13}$ For a video recording of a performance in the Korzo Theatre in The Hague in 1992, see www.youtube.com/watch?v=53MhO6FQEag (accessed 18 September 2016).

${ }^{14}$ For a video recording of the restored Ideofoon 1 at the Witteveen + Bos Award 2011 in Deventer, the Netherlands, see www. youtube.com/watch?v=blqI6AfA7GM; in The Hague in 2015, at Festival Dag in de Branding, see https://vimeo.com/128601569 (accessed 18 September 2016). For pictures of the re-installation of Ideofoon 1 and Ideofoon 3 at the Witteveen + Bos Award 2011 in Deventer, the Netherlands, see www.kunsttechniekprijs.nl/nl/ winnaars/dick-raaijmakers/ (accessed 6 January 2017)
} 


\subsubsection{Raaijmakers in the international histories of electronic music}

Raaijmakers is mentioned in most of the above discussed histories of electronic music, but only as the co-author of the first electronic 'pop music' (Collins et al. 2012: 84; Manning 2013: 148; Holmes 2016: 474-6). When Raaijmakers worked at the Philips Natlab studio as technical assistant to Edgard Varèse, for Poème Électronique, he was asked by Philips to make some popular music to explore the commercial potential of the new electroacoustic equipment. He did so, between 1956 and 1963, in collaboration with jazz composer Tom Dissevelt, but not under his own name: as Kid Baltan (which is an anagram of Dick Natlab). This music was released on several records $(1957,1959$, 1960, 1961, 1968) and attained a cult status. But for a long time, Dick Raaijmakers did not consider these 'Popular Electronics' part of his own oeuvre. In 2004, Raaijmakers's and Dissevelt's Popular Electronics were released, in close collaboration with Raaijmakers, as a CD box set with booklets providing extensive historical documentation (Popular Electronics 2004). ${ }^{15}$

Remarkably, this side-path in Raaijmakers's oeuvre is his only work that is mentioned in the international histories of electroacoustic music. Why? I can see several factors:

- it was pioneering work, both technically and musically - the first popular electronic music;

- it was already described early on (e.g. Prieberg 1960);

- the uniqueness and innovation of Raaijmakers's subsequent work was not so much related to the invention of new technology, as to conceptual, artistic and musical work and to performance; while these histories are focused on 'firsts', on 'beginnings' and on technological innovation; ${ }^{16}$

- Dick Raaijmakers did not travel internationally and his work was seldom performed outside of the Netherlands;

- a large and important part of his oeuvre consists of works that are uniquely bound to the specific occasion of its performance (in the Netherlands);

- Raaijmakers's texts were written in Dutch; during the majority of his career, English translations were not easily available;

- the extensive documentation and release of recordings of his 'serious' electronic music and art came rather late in his career.

\footnotetext{
${ }^{15}$ This CD box set contains early electronic music by Dick Raaijmakers, Tom Dissevelt and Henk Badings. For a detailed historical account, see Tazelaar (2013).

${ }^{16}$ E.g. Holmes 2016: xiv-xv. "I also use the word "experimental" to underscore that the book is primarily about historical beginnings in the art of electronic music, both technologically and musically' (Holmes 2016: xv)
}

Thus, positive factors with regard to the inclusion of Kid Baltan/Dick Raaijmakers were: a focus of the histories on pioneers, novelties and technological progress; and the early availability of recordings of the Kid Baltan pieces. Negative factors with regard to Raaijmakers's inclusion in international historical overviews of electronic music were: the late availability of the documentation of his other work; lack of an international network, related to location, travelling and language; and an apparent lack of interest of the electroacoustic histories in artistic and musical developments that do not promote technological innovation.

\subsection{Michel Waisvisz (1949-2008)}

\subsubsection{Michel Waisvisz: work and documentation}

One of the other few Dutchmen who are mentioned in the books on electronic music is Michel Waisvisz. He was director of the Studio for Electro-Instrumental Music (STEIM) in Amsterdam (since 1981) and he performed with his own electronic instruments or gestural controllers The Hands (Figure 1). He also developed other electronic instruments or interfaces, such as the analogue Crackle Box, the analogue Crackle Synth and the controller the Web; more controllers and software were also developed at STEIM.

The first version of The Hands was developed in 1984, just after the arrival of MIDI. It controlled a synthesiser (DX7, FM-synthesis). Later versions controlled more and different synthesisers, computers and samplers and MIDI sequences triggering synthesisers or sampler sounds. Later on, the software LiSa was developed at STEIM for live sampling and manipulating sounds and used with The Hands. This had great consequences for music and performance: different sounds, different sound structures and different interaction between the music and the sonic environment. ${ }^{17}$ For example, with the live sampling feature, Michel Waisvisz played together with other musicians, sampling their sound during performance, as well as manipulating and developing it.

Waisvisz and his collaborators developed The Hands slowly. In interviews Waisvisz often stressed the importance of not changing the instrument all the time, but allowing himself time to learn the instrument and to develop his music.

By freezing the design modifications and extensions when The Hands were physically stable and durable, it became

${ }^{17}$ Examples of different phases of Waisvisz's music for The Hands: Touch Monkeys, performance at Centre Pompidou, Paris, in 1986, recording at Médiathèque de l'Ircam - http://medias.ircam.fr/ x31a933_touch-monkeys-michel-waisvisz; live sampling of the sound of audience - https://youtu.be/pYfRORkuPX8; performance at NIME conference 2003 with live sampling of his own voice - https:// youtu.be/SIfumZa2TKY; see also STEIM's Youtube channel STEIMTUBE -www.youtube.com/user/STEIMTUBE (accessed 6 January 2017). 


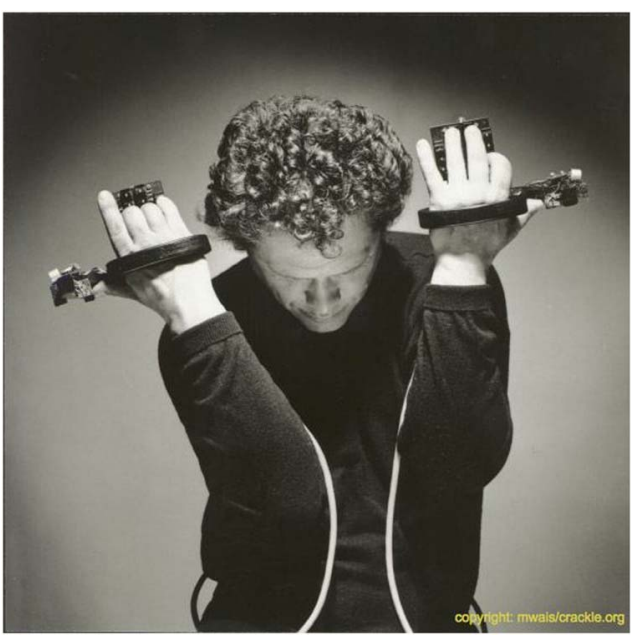

Figure 1. Michel Waisvisz and The Hands. (C) archive Michel Waisvisz/Kristina Andersen.

possible to focus on the musical intent beyond the novelty of the devices and engage in the aesthetic and musical considerations, rather than the technical details that lie behind the interface. (Torre and Andersen 2017: 134)

[I]t was through his commitment to build a practice around them over a long period of time and develop a unique and personal set of expressions and virtuosic skills, which instituted them as instruments for musical expression. (Torre and Andersen 2017: 135)

Thus, Michel Waisvisz took the musical aspect very seriously. An excerpt from his contribution to NIME 2006 illustrates this (Figure 2).

Waisvisz advocated an ideology of live performance, presence and touch. He refused to issue recordings of his work for a large part of his career (1978 to 2005). The music existed only in the here and now: you had to be there to experience it. Only at the end of his life were two CDs with his music released (Waisvisz 2005; Sehnaoui and Waisvisz 2008). (However, several video recordings and some radio recordings ${ }^{18}$ were made during his career.) There is little documentation of the technical aspects of his electromusical instruments: 'Despite being often cited in the relevant literature, however, the documentation concerning the sensor architecture, design, mapping strategies, and development of these data gloves is sparse' (Torre, Andersen and Baldé 2016: 22).

Nevertheless, Waisvisz kept many things in his archive, such as photos, drawings, instruments, models, printed out code, posters, audio, video, software, etc., 'in any format you can think of', including all versions of The Hands and its software

\footnotetext{
${ }^{18} \mathrm{~A}$ part of a radio recording of a performance of Michel Waisvisz with The Hands, Rupture (part 3), performed in 2004 in Amsterdam and recorded by VPRO Café Sonore, was released on Anthology 2011.
}

\section{Panel Discussion moderated by Michel Waisvisz Manager or Musician?}

About virtuosity in live electronic music.

Do we operate our electronic systems or do we play them?

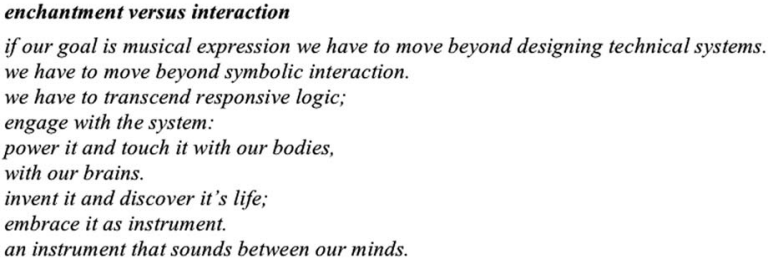

Figure 2. Excerpt from Michel Waisvisz's introduction to a panel discussion in Proceedings of the 2006 International Conference on New Interfaces for Musical Expression (NIME06), Paris, France. http://recherche.ircam.fr/equipes/ temps-reel/nime06/proc/nime2006_415.pdf.

(Andersen 2016). Since his death in 2008, Michel Waisvisz's partner Kristina Andersen, an artist and researcher herself, is taking care of Waisvisz's archive. She notes that the documentation from the 1960s and 1970s, when storage media were expensive, thus forcing selection, is much better and easier to archive than the documentation from the 1980s and 1990s, with its problematic formats of digital storage. Moreover, in the 1980s photographs became self-made on low-quality cameras instead of by hired professional photographers. While at first Kristina Andersen was struggling with a systematic master plan for the archiving, she gradually came to realise that it would be important for Michel, for herself and for others involved, to 'do the archiving in a living way' (ibid.). This is both a strategy and a pragmatic approach. Projects are planned in cooperation with others, while visiting researchers come with their own requests. Publishing, getting it out into the world, has priority. ${ }^{19}$

One such project is the remaking of the Crackle Synth. Two instruments have survived - one in working order, the other not - and there are some incomplete drawings. An old Crackle Synth was still being used, but it was malfunctioning; while for an instrument, it is essential that it can be played. Now three new Crackle Synths are being made, true to the original, but with updated components where possible. These are for three artists, 'muses' ${ }^{20}$ who in the past have played an old Crackle Synth and will be using the new one in their future performances. The remaking of the Crackle Synth is being documented by drawings, photos, recordings and a report.

${ }^{19}$ Currently, there are two recent academic articles on The Hands (Torre et al. 2016; Torre and Andersen 2017) and a PhD-research on STEIM's archive by Andi Otto.

${ }^{20}$ Jan Werner, Mazen Kerbaj and James Fei. 


\subsubsection{Michel Waisvisz in the international histories of electronic music}

While Waisvisz's Hands are often mentioned in the international overviews of electronic music, his music is not discussed at all. ${ }^{21}$ For example, there is no mention of the difference between controlling a synthesiser or live sampling and its musical implications for sound, structure and performance practice. This neglect of Waisvisz's music contrasts with the importance he himself attached to the musical aspect of his practice.

Why was Waisvisz so successful, being one of the few Dutch electroacoustic artists mentioned in these books? And why was his music neglected? I can identify several factors:

- Michel Waisvisz had a good international network: he liked to travel, he liked the United States, he invited many international guest-artists to work at STEIM and he was a founding member of the NIME conference; STEIM's website and presentations are in English; there was much interest in Waisvisz's work in academia and in the United States; 'it helped that he liked to talk and was approachable' (Andersen 2016).

- The emphasis in the books on technological innovation, on 'beginnings' and on electroacoustic musical instruments explains the interest for his first Hands and the disinterest in its subsequent development.

- The lack of available documentation and recordings of his work may explain the neglect of his music.

- STEIM and Waisvisz did not publish much, neither academic articles nor recordings; STEIM is not part of academia, hence there were no obligations to publish academic papers or books.

Thus, positive factors for the inclusion of Waisvisz in the electronic music histories were: the electroacoustic musical histories' focus on pioneers, novelties and technological progress; and Waisvisz's network. The electroacoustic musical histories' apparent disinterest in the musical aspect of electronic music is a negative factor for the discussion of Waisvisz's work. The lack of academic publications may explain the lack of detailed information on Waisvisz's electromusical instruments in the books on electronic music.

\subsection{Others: Huba de Graaff}

There are many Dutch makers of electroacoustic music who are not mentioned in the books on electronic music discussed above. To give some established

\footnotetext{
${ }^{21}$ See Manning (2013: 454-5) for a short discussion of Waisvisz's controllers The Hands and the Web, and the Crackle Box and Crackle Synth. See Holmes (2016: 284-5) for a very short description of The Hands. Chadabe (1997: 228) mentions several compositions by Waisvisz, but without providing any musical information, description or analysis. Collins et al. (2012) mentions Waisvisz only in relation to STEIM's live sampling software LiSa (184) and pays attention to Laetitia Sonami's Lady's Glove instead.
}

names: Tera de Marez Oyens (1932-96), Ton Bruynèl (1934-98), Roderik de Man (b. 1941), Jacob ter Veldhuis (b. 1951), ${ }^{22}$ Huba de Graaff (b. 1959), René Uijlenhoet (b. 1961), Michel van der Aa (b. 1970), and many others. What these composers have in common is that they are not connected with a technical novelty ${ }^{23}$ or an institute and that the musical or artistic aspects are central in their work. They all often combine electroacoustic technology with acoustic musical instruments in a concert or music theatre setting. Here, I would like to focus on one of these composers, Huba de Graaff, not because she is representative of the others - her oeuvre is unique in many respects - but because in her work several issues come to the fore that are of essential significance in relation to history, sources and preservation.

Huba de Graaff is a composer who not only creates sounds and writes musical notation, but also makes her own electronic performance devices and theatrical concepts, in collaboration with others, mostly in the context of music theatre. Her oeuvre consists of about 85 works varying in length from one minute to one and a half hours, for solo voice or solo instrument, ensemble or orchestra, and mainly with diverse forms of electroacoustics. ${ }^{24}$ Her work deals with sound technology and media in an ironic way and is often a playful reflection on existing technology and its function. Thus, it is not focused on the newest technology or on innovation in a linear, technological sense. An example is her music theatre work Lautsprecher Arnolt (2003), in which specially built loudspeakers function as personae, as dramatic objects and as theatrical props (Bosma 2013, 2014, 2016b). ${ }^{25}$ Other works include a large-scale combination of performance and installation (Corenicken, 1991), ${ }^{26}$ a sound dress (Japon Fuzz, 1991), a piezo grid sound installation (1992), ${ }^{27}$ a media opera (De dood van Poppea, 2006), ${ }^{28}$ and several theatrical-musical works.

With such elaborate music-theatrical productions with specifically built electroacoustic props, the preservation and dissemination of her work is highly problematic. Huba de Graaff tries to retain as much as possible of her old works and still has software, MIDI and audio files, old computers, some specific objects

\footnotetext{
${ }^{22} \mathrm{JacobTV}$ is mentioned by Collins et al. (2012: 188; see n. 10).

${ }^{23}$ Michel van der Aa's chamber opera for soprano and 3D film Blank out (2016) can indeed be called a novelty, but it is obviously too recent to be mentioned in the electronic histories discussed here.

${ }^{24}$ For the work list of Huba de Graaff, see www.hubadegraaff.com/ all-work-huba-de-graaff/ (accessed 6 January 2017).

${ }^{25}$ Lautsprecher Arnolt: composition and concept, Huba de Graaff; text and stage direction, Erik-Ward Geerlings; visual design and installations, Bart Visser; performance, Marien Jongewaard. http://www hubadegraaff.com/lautsprecher-arnolt/ (accessed 6 January 2017).

${ }^{26}$ www.hubadegraaff.com/corenicken/ (accessed 6 January 2017).

${ }^{27}$ www.hubadegraaff.com/studie-piezo-models/ (accessed 6 January 2017).

${ }^{28}$ www.hubadegraaff.com/de-dood-van-poppaea/ (accessed 6 January 2017).
} 


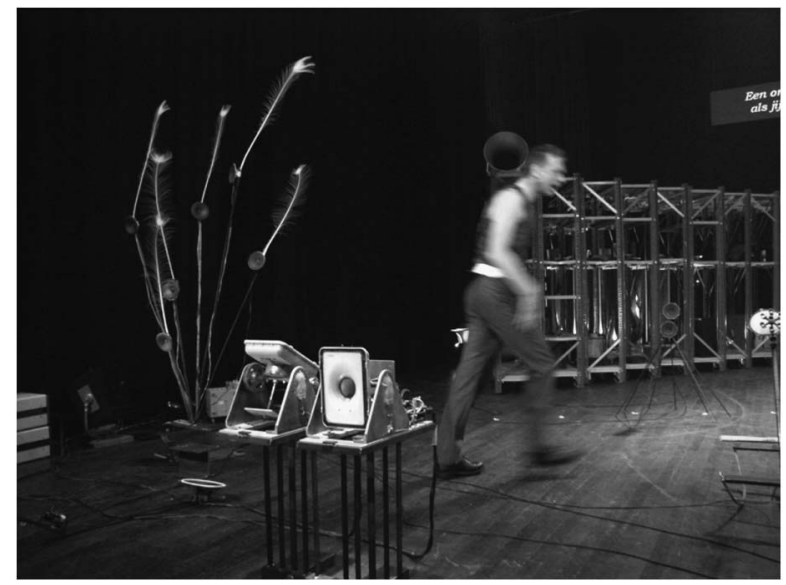

Figure 3. Speaker objects of Lautsprecher Arnolt on stage. Foreground: rotating loudspeakers. Photo by Bart Visser.

and some video recordings (de Graaff 2016a). Nevertheless, a general lack of documentation is problematic for the preservation, re-performance and dissemination of her work. Problematic for preservation are:

- the lack of a complete score;

- the lack of complete documentation, technical and otherwise;

- the storage of the objects - several have disappeared and there is a lack of storage space;

- the specificity of the performers;

- video registration (not high quality or not an adequate representation).

For example, what is left of Lautsprecher Arnolt that was last performed in 2005? There is a libretto. There are fragments of a score. Huba de Graaff retained all MIDI, Logic and audio files. There are photographs. There is a video registration, but she is not happy with its quality. Huba de Graaff personally kept the rotating speakers (see Figure 3 ) made and programmed by her, together with the Atari computer and software that controls the speaker, and a duplicate. (December 2016, the Dutch national Performing Arts Fund assigned funding to Huba de Graaff to develop a new work for these rotating speakers (de Graaff 2016b); therefore, she must make sure that the speakers are working and programmable.) On the other hand, there is no complete score of Lautsprecher Arnolt. It is unclear where the other loudspeaker objects are; most loudspeaker objects are in a storage place of another theatre group and some have, without permission, been used for other productions. There is no highquality video registration. There is little technical documentation.

Huba de Graaff has specific ideas about preservation, inspired by her re-performance, or re-construction, of Michael van Biel's Jagdstück (1966) in 1985. She states that with this kind of music, re-performance is always a re-construction and a re-interpretation. Moreover, documentation is a re-interpretation in a different medium; to stress the importance of the medium, she quotes McLuhan's slogan 'the medium is the message' this is the reason that Huba de Graaff is not happy with the video recordings of her work. Huba de Graaff remarks that when she was younger, making more experimental works and feeling more insecure, she did not pay attention to the documentation and preservation of her work. However, being older now, feeling more secure and being more conscious about this problematic, she is documenting her work better (de Graaff 2016a).

\section{PRESERVATION AS PERFORMANCE}

Live electronic music and electroacoustic music theatre and performance art are far more difficult to preserve than tape music or music for standard acoustic instruments notated in scores. In the cases discussed above, both artistic, ontological and practical considerations led to ideas and practices that I name 'preservation as performance'. While one can argue that preservation is always performative, 'doing', both keeping and changing its objects, the music discussed here is particularly preserved through new performances, new installations and new publications that constitute re-constructions, re-uses and re-interpretations, 'archiving in a living way'. Preservation as performance is not a standard procedure, but consists of special projects that relate both to the past and to new actors, new situations and new interpretations.

The term 'preservation as performance' makes clear the performative aspects of all preservation and history: these can and will only be brought about by acts that involve both repetition and change. While music is in itself already so ephemeral, it is important to take care of its sources and traces, that is, documentation in various ways - but without stifling and devitalising it. While other musical practices are or seem to be more standardised, traditional or communal than electronic music, and thus less prone to obsolescence, sooner or later they will encounter similar problems to those epitomised by electronic music. The only way for music to survive is by keeping it alive, in and through living, experiencing, thinking and practising bodies, based on traces of the past, enduring and vulnerable, effecting identity and change.

\section{CONCLUSION}

In comparison to histories of Western art music, histories of electronic music have a greater emphasis on technology and on technological innovation than on musical and artistic aspects. Histories of electronic music are very much about technologies, institutes and specific people: inventors and composers. Thus, for the 
inclusion in these histories, networks and personal communication are important. Another important aspect is the emphasis on inventions, on beginnings, rather than on musical, artistic and technical elaboration. There is also little attention for a critical, ironic or self-reflexive use of sound technology. The emphasis is on the invention or introduction of technologies, not on their subsequent use ${ }^{29}$ or reception. Thus, essential aspects are not covered in these histories of electronic music.

It is noteworthy that the newest historical account discussed here, Collins et al. (2012), has in many respects a somewhat different orientation, discussing popular music, recent alternative trends such as electronica and interdisciplinary realms, and paying more attention to musical and sociocultural aspects as well, presenting electroacoustic technology more in context. It thus links to recent developments in sound studies, media studies and musicology.

An interesting inverse cross-influence could come from taking Davies's critique on historical musicology from the perspective of electronic music seriously (Davies 2001). Whereas electronic music histories fall short in their attention to the music itself, general histories of Western art music do not pay enough attention to the various forms, versions and generations of musical instruments, and the related technologies, as an essential part of musical culture and musical sound.

In order to pay more attention to the musical aspects, it is crucial to have more access to the music itself. However, for live electronics, interdisciplinary electroacoustic music theatre, installations, improvisations and so on, preservation beyond its unique performances is very problematic. The use of various analogue and/or digital electronic technologies, instruments and media, the intermingling of electronic music with various other disciplines (such as art, dance, theatre), the upheaval or stretching of the concept of the musical work and the departure from tradition causes new and serious problems to its preservation, such as early obsolescence of the experimental technology and a lack of standards. Moreover, a focus on the unique present, on decay, or on obsolete technology are often aesthetic features of such music, adding a reflexive layer to the problematics of preservation - this is also an essential aspect that makes it impossible to 'freeze' this musical art in time. Scores or recordings, if they exist at all, are not sufficient. The works and practices of Dick Raaijmakers, Michel Waisvisz and Huba de Graaff seem to resist documentation, ontologically and practically; but on the other hand, there is a desire for its documentation, dissemination and canonisation.

For the musical-artistic heritage of Dick Raaijmakers, Michel Waisvisz and Huba de Graaff, preservation

${ }^{29}$ Collins et al. (2012) is an exception. means making something new while being faithful to the past. It is therefore that I propose to regard preservation as performance. To do so, it is important to find access to various manifestations of the work, to various sources and traces. This music only remains alive when we are not solely interested in linear innovation, but also in a profound relation with the past, in reworking the past.

\section{Acknowledgement}

This article is an elaboration of the author's paper presented at the conference Alternative Histories of Electronic Music, London, 14 April 2016.

\section{REFERENCES}

Andersen, K. 2016. Interview with the author, 5 April.

Battier, M. 2004. Electroacoustic Music Studies and the Danger of Loss. Organised Sound 9(1): 47-53.

Bosma, H. 2005. Documentation and Publication of Electroacoustic and Multimedia Compositions at NEAR: Experiences and Experiments. Conference Proceedings of the Electroacoustic Music Studies network 05 conference. www.ems-network.org. Updated version 2008. eContact! 10.x, Canadian Electroacoustic Community, Concordia University, Montreal, Canada, http://econtact.ca/10_x/ bosma_extendedscore.html (accessed 12 May 2017).

Bosma, H. 2006. Musical Washing Machines, ComposerPerformers, and Other Blurring Boundaries: How Women Make a Difference in Electroacoustic Music. Intersections: Canadian Journal of Music 26(2): 97-117.

Bosma, H. 2007. Drive and Native Tongue: Intersections of electroacoustic documentation and gender issues. Electroacoustic Music Studies Network Conference 07, 12-15 June 2007, De Montfort University, Leicester, UK.

Bosma, H. 2013. The Electronic Cry: Voice and Gender in Electroacoustic Music. PhD diss., University of Amsterdam.

Bosma, H. 2014. Playing Loudspeakers, Unsettling Concerts: Gender and Performance in Interdisciplinary Electroacoustic Music. Conference Proceedings of the Electroacoustic Music Studies Conference 2014. www. ems-network.org.

Bosma, H. 2016a. Computer Music as Born-Digital Heritage. Proceedings International Computer Music Conference 2016, Utrecht.

Bosma, H. 2016b. Unsettling Performances, Soundwalks and Loudspeakers: Gender in Electroacoustic Music and Other Sounding Arts. In M. Cobussen, V. Meelberg and B. Truax (eds.) The Routledge Companion to Sounding Art. New York: Routledge.

Burkholder, J. P., Grout, D. J. and Palisca, C. V. 2014. A History of Western Music, 9th edn. New York: W. W. Norton.

Canazza, S. and Vidolin, A. 2001. Introduction: Preserving Electroacoustic Music. Journal of New Music Research 30(4): 289-93.

Chadabe, J. 1997. Electric Sound: The Past and Promise of Electronic Music. Upper Saddle River, NJ: Prentice Hall.

Collins, N., Schedel, M. and Wilson, S. 2012. Electronic Music. Cambridge: Cambridge University Press. 
Cuervo, A. P. 2008. Ephemeral Music: Electroacoustic Music Collections in the United States. Research Forum Peer-Reviewed Research Papers. http://dx.doi.org/doi: 10.7282/T3KH0Q1P.

Davies, H. 1968. Répertoire international des musiques électroacoustiques/International Electronic Music Catalog. Paris and Trumansburg, NY: Groupe de Recherches Musicales de l'ORTF and Independent Electronic Music Center, Inc.

Davies, H. 2001. The Preservation of Electronic Musical Instruments. Journal of New Music Research 30(4): 295-302. de Graaff, H. 2016a. Interview with the author, 7 April.

de Graaff, H. 2016b. Email correspondence with author, 25 December.

Douglas, J. 2007. InterPARES 2 Project - General Study 03 Final Report: Preserving Interactive Digital Music - The MUSTICA Initiative. www.interpares.org/display_file. cfm?doc=ip2_gs03_final_report.pdf (accessed 12 May 2017).

Emmerson, S. 2006. In What Form Can 'Live Electronic Music' Live on? Organised Sound 11(3): 209-19.

Griffiths, P. 1981. Modern Music: The Avant Garde Since 1945. London: Dent.

Grout, D. J. 1980. A History of Western Music, 3rd edn. New York: W. W. Norton.

Guercio, M., Barthélemy, J. and Bonardi, A. 2007. Authenticity Issue in Performing Arts using Live Electronics. Proceedings 4th Sound and Music Computing Conference (SMC 07), Lefkada, Greece, 11-13 July.

Holmes, Th. 2016. Electronic and Experimental Music: Technology, Music, and Culture, 5th edn. New York: Routledge.

Longton, M. 2007. InterPARES 2 Project - General Study 04 Final Report: Recordkeeping Practices of Composers. www.interpares.org/display_file.cfm?doc=ip2_gs04_final_ report.pdf (accessed 12 May 2017).

Manning, P. 2013. Electronic and Computer Music, 4th edn. Oxford: Oxford University Press.

Mooney, J. 2015. Hugh Davies's Electronic Music Documentation 1961-1968. Organised Sound 20(1): 111-21.

Morgan, R. P. 1991. Twentieth-century Music: A History of Musical Style in Modern Europe and America. New York: W. W. Norton.

Mulder, A. and Brouwer, J. 2007. Dick Raaijmakers: Monografie. Rotterdam: V2_Publishing (in English: 2008, Dick Raaijmakers: A Monograph).

Oskamp, J. 2011. Onder stroom: Geschiedenis van de elektronische muziek in Nederland. Amsterdam: Ambo/ Anthos.

Polfreman, R., Sheppard, D. and Dearden, I. 2006. Time to Re-wire? Problems and Strategies for the Maintenance of Live Electronics. Organised Sound 11(3): 229-42.
Prieberg, F. 1960. Musica ex Machina: Über das Verhältnis von Musik und Technik. Berlin: Ullstein.

Roeder, J. 2004. Preserving Authentic Interactive Digital Artworks: Case Studies from the InterPARES Project. International Cultural Heritage Informatics Meeting: Proceedings from ICHIM 04, Berlin, Germany, 30 August-2 September 2004, Xavier Perrot (ed.). Toronto: Archives \& Museum Informatics.

Roeder, J. 2008. Art and Digital Records: Paradoxes and Problems of Preservation. Archivaria 65: 151-63.

Swift, K. J. 2011. Grappling with Donald Jay Grout's Essays on Music Historiography. Journal of Music History Pedagogy 1(2): 135-66. www.ams-net.org/ojs/index.php/ jmhp/article/view/7 (accessed 18 September 2016).

Taruskin., R. 2005. The Oxford History of Western Music. Oxford: Oxford University Press.

Tazelaar, K. 2013. On the Threshold of Beauty: Philips and the Origins of Electronic Music in the Netherlands 1925-1965. Rotterdam: V2_Publishing.

Teruggi, D. 2004. Electroacoustic Preservation Projects: How to Move Forward. Organised Sound 9(1): 55-62.

Torre, G., Andersen, K. and Baldé, F. 2016. The Hands: The Making of a Digital Musical Instrument. Computer Music Journal 40(2): 22-34.

Torre, G. and Andersen, K. 2017. Instrumentality, Time and Perseverance. In T. Bovermann, A. de Campo, H. Egermann, S.-I. Hardjowirogo and S. Weinzierl (eds.) Musical Instruments in the 21st Century: Identities, Configurations, Practices. Singapore: Springer.

van Bergen, M. 2013. Dutch dance: 25 jaar dance in Nederland. Amsterdam: Xander Uitgevers.

Wetzel, D. B. 2006. A Model for the Conservation of Interactive Electroacoustic Repertoire: Analysis, Reconstruction, and Performance in the Face of Technological Obsolescence. Organised Sound 11(3): 255-72.

\section{DISCOGRAPHY}

Anthology of Dutch Electronic Music 1999-2010. 2011. Aalsmeer: Basta 3093042, CD set, production: Hannah Bosma / Music Center the Netherlands.

The Complete Tape Music of Dick Raaijmakers. 1998. Amsterdam: NEAR Donemus (René Uijlenhoet) (3 CDs and a 200-page booklet, CV-NEAR 9/10/11); re-issue (with new graphical design and without Dutch text) 2006, Aalsmeer: Basta Music, in collaboration with NEAR Donemus, Amsterdam (Hannah Bosma).

Popular Electronics: Early Dutch Electronic Music From Philips Research Laboratories, 1956-1963. 2004. Aalsmeer: Basta 30-9141-2 (4 CDs and 7 booklets).

Sehnaoui, Christine and Waisvisz, Michel. 2008. Shortwave. Beirut: Al Maslakh MSLKH 08..

Waisvisz, Michel. 2005. In Tune. Köln: Sonig 45, CD. 